\title{
Vascular Endothelial Growth Factor (VEGF) - 460C/T (rs833061) Gene Polymorphism as a Risk Factor for Diabetic Retinopathy in Type 2 Diabetes Mellitus in Bali
}

\section{Astri Meliana ${ }^{1}$, Desak Made Wihandani², Ni Nyoman Ayu Dewi ${ }^{2}$, I Made Winarsa Ruma², Anak Agung Mas Putrawati Triningrat ${ }^{3}$}

${ }^{1}$ Faculty of Medicine, Udayana University, Denpasar, Bali, Indonesia, 80113

${ }^{2}$ Biochemistry Department, Faculty of Medicine, Udayana University, Denpasar, Bali, Indonesia, 80113

${ }^{3}$ Ophthalmology Department, Faculty of Medicine, Udayana University, Denpasar, Bali, Indonesia, 80113

\begin{abstract}
Introduction: Diabetic retinopathy (DR) is a microvascular disorder of the retina caused by hyperglycemia in the blood vessels and is the most common complication in the eye due to diabetes mellitus (DM). The aim of this study was to determine the VEGF $-460 \mathrm{C} / \mathrm{T}$ gene polymorphism as a risk factor for diabetic retinopathy in T2DM patients in Bali.

Materials and Methods: The design of this study was case-control with 27 cases of type 2 DM with DR and 29 cases without RD as controls. The VEGF-460C/T polymorphism in DNA was detected using PCR and DNA sequencing at rs833061 to see the distribution of the $\mathrm{C} / \mathrm{T}$ allele variation. Data were analyzed using chi-square test.
\end{abstract}

Results: Based on bivariate analysis comparing homozygous TT genotype variants, heterozygous CT and wild-type CC in this study, no significant relationship was found with the incidence of DR ( $\mathrm{p}=0.742)$.

Conclusion: Polymorphism of the VEGF460C/T gene (rs833061) can be concluded as an irrelevant factor with the risk of developing DR in type 2 diabetes mellitus patients in Bali.

Keywords: VEGF -460C/T, Diabetes Mellitus, Polymorphism, Risk Factors

\section{INTRODUCTION}

Diabetes Mellitus (DM) is a disease caused by metabolic disorders, which are characterized by increased blood sugar levels or hyperglycemia due to abnormalities in insulin action or insulin secretion or both. Another complex etiology that causes DM are genetic factors and an unhealthy lifestyle. In several epidemiological studies, there is a tendency to increase the incidence and prevalence of T2DM in various parts of the world. ${ }^{1}$ Until now DM is still a major health problem in the world. The World Health Organization (WHO) predicts an increase in the number of people with T2DM in the coming years in Indonesia from 8.4 million in 2000 to around 21.3 million in $2030 .^{2}$ Meanwhile, based on predictions from the International Diabetes Federation (IDF), in 2013-2017 there was an increase in the number of people with DM from 10.3 million to 16.7 million in $2045 .^{3}$ In addition to the increase in the prevalence of people with diabetes, complications of type 2 diabetes can be in the form of disorders of the blood vessels, both macrovascular and microvascular. These macrovascular disorders commonly cause heart disease, hypertension, kidney dysfunction and stroke. Meanwhile, microvascular disorders can be in the form of neuropathy and retinopathy. ${ }^{4}$

Diabetic retinopathy (DR) is a visual disorder that most often occurs in patients 
with T2DM. Diabetic retinopathy is a visual disorder that is damage to the retinal blood vessels that is chronic progressive and the most common cause of blindness in the age of 20-74 years. Diabetic retinopathy can be divided into two stages, namely, nonproliferative diabetic retinopathy (NPDR) and proliferative diabetic retinopathy (PDR). In T2DM when the diagnosis is made, about $25 \%$ of patients already suffer from NPDR, the mildest form of diabetic retinopathy, which is often asymptomatic or asymptomatic. $^{5}$

VEGF is one of the genes involved in the pathogenesis of DR. VEGF is a glycoprotein that has the ability to induce angiogenesis by altering retinal capillary permeability and increasing phosphorylation of proteins involved with tight junctions such as zonula occludens. Based on the results of the meta-analysis conducted by Gong and Sun in 2013 the results of the 460C/T polymorphism, the $\mathrm{C}$ allele showed a $70 \%$ increase in promoter activity over the $\mathrm{T}$ allele. ${ }^{6}$ The study showed significant results where the rs833061 (-460C/T) polymorphism had a significant relationship that can increase VEGF gene expression, and increase susceptibility to the incidence of diabetic retinopathy. In addition, in a study conducted by Paine et al. (2012), rs833061 (-460C/T) in the VEGF gene was significantly associated with proliferative diabetic retinopathy (PDR) in T2DM patients. ${ }^{7}$ However, in a study involving 500 patients in China, no significant association was found between the rs833061 polymorphism $(-460 \mathrm{C} / \mathrm{T})$ and $\mathrm{DR}$ in patients with T2DM. ${ }^{8}$ Apart from the diversity of study results related to the relationship between the VEGF $-460 \mathrm{C} / \mathrm{T}$ gene polymorphism and risk factors for DR in type 2 DM patients, the authors wanted to know whether the VEGF-460C/T gene polymorphism in the promoter region was a risk factor for DR in T2DM patients in Bali. This study aimed to determine the VEGF 460C/T gene polymorphism as a risk factor for diabetic retinopathy in T2DM patients in Bali.

\section{MATERIALS AND METHODS Study Design}

This study was a case control study using blood sample from 27 cases of T2DM with DR and 29 cases without DR as controls. Study was conducted at Biochemistry Laboratory, Faculty of Medicine, Udayana University.

\section{DNA Amplification and Sequencing}

This study was conducted using DNA template that were isolated before using DNA isolation kit. To amplified the DNA of VEGF rs833061, forward primer (5'- TCCAAAGCCCATTCCCTCTT-3'), reverse primer (5'GGGAGAGGGACACACAGATC-3'), and GoTaq ${ }^{\circledR}$ Green Master Mix PCR Kit from Promega were used. The setting temperatures were used as follow; (i) predenaturation; $94^{\circ} \mathrm{C}$ for 1 minute; (ii) denaturation at $72^{\circ} \mathrm{C}$ for 7 minutes, annealing at $94^{\circ} \mathrm{C}$ for 30 seconds, $57^{\circ} \mathrm{C}$ for 30 seconds, and extension at $72^{\circ} \mathrm{C}$ for 30 seconds, with a total of 40 cycles for the three processes; (iii) Final extensions; $72^{\circ} \mathrm{C}$ for 5 minutes. Amplification product were then visualized using agarose gel $1 \%$ in electrophoresis procedure. To detect polymorphism in VEGF $-460 \mathrm{C} / \mathrm{T}$, purification and sequencing procedure were done using PCR DNA Fragments Extraction Kit from Geneaid. The results of gene sequencing were then interpreted using SnapGene.

\section{STATISTICAL METHOD}

Characteristic data of the patient were collected from patient's medical record such as age, sex, duration of diabetes, blood pressure (systolic and diastolic), waist circumference, body mass index, HbA1C level, and family history of diabetes. The results of sequencing assessment were categorized into three, namely CC Wild Type, CT Heterozygot, and TT Homozygot. The present of DR of patients was categorized into DR and non DR. Bivariate analysis (Mann Whitney test and Chi Square) were conducted to assess the 
Astri Meliana et.al. Vascular endothelial growth factor (VEGF) -460C/T (rs833061) gene polymorphism as a risk factor for diabetic retinopathy in type 2 diabetes mellitus in Bali.

relationship among variables to dependent variable.

\section{RESULT}

This research was conducted at the Integrated Biomedical Laboratory, Faculty of Medicine, Udayana University from February 2021 to March 2021. This research has obtained an ethical clearance permit from the Ethics Commission of the Faculty of Medicine, Udayana University with number 461/UN14.2.2.VII.14/ LT/2021. The sample used was in the form of stored biological material (BBT) from previous research at the Department of Biochemistry, Faculty of Medicine, Udayana University in the form of DNA isolation from patients with type 2 diabetes mellitus in Bali.

The total sample used is 56 samples. Due to this research using stored biological materials, the data on the basic characteristics of the sample have been obtained and have been described in a bivariate manner which can be seen in table 5.1 .

\begin{tabular}{|c|c|c|c|c|c|}
\hline Parameter & $\begin{array}{l}\text { DR } \\
N=27\end{array}$ & $\begin{array}{l}\text { NDR } \\
N=29\end{array}$ & OR & $95 \% \mathrm{CI}$ & $\mathbf{p}$ \\
\hline $\begin{array}{l}\text { Age } \\
(\text { Mean } \pm \text { SD) }\end{array}$ & $50,37 \pm 6,94$ & $53,69 \pm 9,434$ & - & - & $0,124^{\mathrm{b}}$ \\
\hline$<50$ & $13(48,1 \%)$ & $11(37,9 \%)$ & 0,658 & $0,227-1,909$ & 0,440 \\
\hline$\geq 50$ & $14(51,9 \%)$ & $18(62,1 \%)$ & & & \\
\hline $\begin{array}{l}\text { Duration of Diabetes } \\
\text { (Mean } \pm \text { SD) }\end{array}$ & $7,52 \pm 3,556$ & $5,53 \pm 5,519$ & - & - & $0,119^{\mathrm{b}}$ \\
\hline Waist Circumference & $92,963 \pm 7,758$ & $86,354 \pm 9,422$ & - & - & $0,197 \mathrm{~b}$ \\
\hline BMI & $24,355 \pm 3,024$ & $24,714 \pm 3,462$ & - & - & $0,682 b$ \\
\hline HbA1C & $8,815 \pm 2,083$ & $8,172 \pm 2,344$ & - & - & $0,098 \mathrm{a}$ \\
\hline \multicolumn{6}{|l|}{ Sex } \\
\hline Male & $17(63 \%)$ & $14(48,3 \%)$ & 1,821 & $0,626-5,299$ & 0,269 \\
\hline Female & $10(37 \%)$ & $15(51,7 \%)$ & & & \\
\hline \multicolumn{6}{|l|}{ Family History of Diabetes } \\
\hline Present & $20(74,1 \%)$ & $15(51,7 \%)$ & 2,667 & $0,864-8,235$ & 0,084 \\
\hline Absent & $7(25,9 \%)$ & $14(48,3 \%)$ & & & \\
\hline
\end{tabular}

*Numerical analysis using analysis: ${ }^{a}$ Mann-Whitney, ${ }^{b}$ T-Test. Categorical analysis using Pearson Chi square. The results were statistically significant if $p<0.05$.

Sequencing results in the form of VEGF gene polymorphism variations -460 C/T rs833061 with the grouping of wildtype CC variants, heterozygous CT and homozygous $\mathrm{TT}$ found no significant relationship between the DR and non-DR groups $(p=0.742)$ (Table 5.2).

Table 2. Analysis of Relationship between VEGF -460C/T Polymorphism and DR

\begin{tabular}{|l|l|l|l|}
\hline \multirow{2}{*}{ Parameter } & $\mathbf{D R}$ & \multirow{2}{*}{ P } \\
\cline { 2 - 3 } & $\mathbf{( + )} \mathbf{N = 2 7}$ & $\mathbf{( - )} \mathbf{~ N = 2 9}$ & \\
\hline CC & $24(88,9 \%)$ & $24(82,8 \%)$ & 0,742 \\
\hline CT & $1(3,7 \%)$ & $1(3,4 \%)$ & \\
\hline TT & $2(7,4 \%)$ & $4(13,8 \%)$ & \\
\hline
\end{tabular}

statistically significant if $p<0.05$.

\section{DISCUSSION}

VEGF is a glycoprotein that has the ability to induce angiogenesis, causing increased vascular permeability, thereby weakening the blood retinal barrier and eventually neovascularization at an advanced stage due to upregulation of VEGF in response to retinal ischemia. The VEGF gene has characteristics with a size of $243 \mathrm{~kb}$ which is located on chromosome 6, has 8 exons and 7 introns. ${ }^{6}$ rs833061 is located on the promoter of the VEGF gene. The presence of polymorphisms in this sequence can cause disturbances in the mRNA transcription process, causing disturbances in VEGF gene expression. However, in this study, there was no significant relationship between the VEGF gene polymorphism rs833061 and the incidence of DR in diabetic patients.

In this study, the mean age of patients with DR was $50.37 \pm 6.94$ years, while in NDR patients it was $53.69 \pm 9.434$ years. This finding is quite different from the study conducted by Yuan et al, 2014 which found the mean age of DM patients without a DR diagnosis was $60.95 \pm 9.96$ years and patients with DR were $61.10 \pm$ 
9.47 years for patients with DR and nonproliferative and $60.66 \pm 8.54$ years for patients with proliferative DR. ${ }^{9}$ While the results are quite close to these findings found in the study of Yang et al, 2011 with a mean age of DR patients of $48.68 \pm 9.58$ years, while for NDR patients the mean age of $50.45 \pm 8.00$ years. ${ }^{10}$ In terms of patient gender, the sex distribution in this study was fairly balanced with 31 male sex (17 patients DR vs 14 non-DR patients) and female sex as many as 25 people (10 DR patients vs 15 non-DR patients). Based on bivariate analysis, there was no significant relationship between gender and the incidence of DR in diabetic patients $(p=0.269)$. The results of this study are in line with the research of Yang et al, 2011 which also found results that were not significant related to gender in the incidence of DR ( $p>0.05) .{ }^{10}$ Similar results were also found in the study of Paine et al, 2012 where no statistically significant results were found ( $>00.05){ }^{7}$ Judging from the duration of diabetes suffered by patients, this study found that the average duration of diabetes in patients with DR was $7.52 \pm$ 3.556 years, while for patients without DR it was $5.53 \pm 5.519$ years with the results of bivariate analysis not statistically significant ( $\mathrm{p}>0.05)$. These findings are inversely proportional to the findings of Yang et al, 2011 which found that the mean duration of patients diagnosed with diabetes was higher in patients without DR of $15.06 \pm 4.38$ years compared to patients with a diagnosis of DR of $14.59 \pm 7.52$ years. ${ }^{10}$ However, similar results were found in a study by Yuan et al, 2014 which found a higher mean duration of diabetes in patients with DR $(8.63 \pm 6.24$ years for non-proliferative DR; $11.52 \pm 5.76$ years for DR). proliferative) although this difference was not statistically significant (p>0.05). ${ }^{9}$ Inversely proportional results were also found in the study of Paine et al, 2012 which found the mean duration of diabetes in patients with DR of $15 \pm 8$ years compared to control patients of $17 \pm 5$ years with a significance of $0.001 .^{7}$ Although the results are significant, this difference is inversely proportional to the findings in this study. Then in terms of family history, in this study it was found that the majority of patients were individuals with a family history of diabetes as many as 35 people, but in the bivariate analysis there were no significant results $(\mathrm{p}=0.084)$. These findings are in contrast to the study of Chisha et al, 2017 which found the majority of patients in their study did not have a family history of being diagnosed with diabetes. ${ }^{11}$ However, in the study of Maghbooli et al, 2014 found similar results to this study, where individuals with a family history of diabetes had a significant relationship with the incidence of $\mathrm{RD}(\mathrm{p}=$ $0.04){ }^{12}$

Based on waist circumference, this study found that patients with DR had a larger mean waist circumference than patients without DR $(92,963 \pm 7,758 \mathrm{~cm}$ vs. $86.354 \pm 9,422 \mathrm{~cm}$ ) with $\mathrm{p}$ value $=0.09$ on the results of bivariate analysis. Meanwhile, in the measurement of BMI, patients with DR had a lower mean BMI than patients without DR $(24,355 \pm 3.024 \mathrm{Kg} / \mathrm{m} 2$ vs $24,714 \pm 3,462 \mathrm{Kg} / \mathrm{m} 2)$. These findings are in line with the research by Yuan et al, 2014 which found a fairly narrow difference in BMI between patients with DR and without DR $(24.21 \pm 2.75 \mathrm{Kg} / \mathrm{m} 2$ vs. $25.27 \pm 3.01$ $\mathrm{Kg} / \mathrm{m} 2) .{ }^{9}$ However, the opposite result was found in the study of Yang et al, 2011 which found that patients with DR had a higher mean BMI than patients without DR (24.79 $\pm 4.36 \mathrm{Kg} / \mathrm{m} 2$ vs $24.55 \pm 4.00 \mathrm{Kg} / \mathrm{m}^{2}$ ) although statistically this difference was not significant $(\mathrm{p}>0.05)$. Furthermore, in terms of HbA1C levels, this study showed that patients with DR had higher HbA1C levels than the non-DR group $(8.815 \pm 2.083$ vs $8.172 \pm 2.344)$ although in the bivariate analysis there were no significant results ( $\mathrm{p}$ $=0.283$ ). The results of this study are in line with the research of Yang et al, 2011 which found that patients with DR had a higher mean HbA1C level of $7.93 \pm 1.67$ compared to the non-DR group of $7.07 \pm 1.39$ with statistically significant results $(\mathrm{p}<0.001) .{ }^{10}$ 
Judging from the genotype variants obtained based on the results of the VEGF $460 \mathrm{C} / \mathrm{T}$ rs833061 gene sequencing it was found that the majority of samples did not experience Single Nucleotide Polymorphism (SNP)/wild type (CC genotype) as many as 48 samples (24 samples in the DR group, 24 samples in the DR group). non-DR). While the rest are CT heterozygous genotypes with 2 samples (1 sample in the DR group, 1 sample in the non-DR group) and 6 samples with the TT genotype (2 samples in the DR group, 4 samples in the non-DR group). The results of this study are inversely proportional to the findings in the study of Yang et al, 2011 which found that the dominant sample of this study had SNP with the TT genotype as many as 65 samples (51.2\%) in the DR group and 81 samples (58.7\%) in the non DR with statistically significant results $(\mathrm{p}=0.021) .{ }^{10}$ Similar results were also found in the study of Paine et al, 2012 which found 152 samples (60.07\%) of the TT genotype in the DR group and 167 samples (69.58\%) in the control group with statistically significant analysis results $(\mathrm{p}=$ $0.004){ }^{7}$ Based on bivariate analysis comparing homozygous TT genotype variants, heterozygous CT and wild type CC in this study, no significant relationship was found with the incidence of DR ( $\mathrm{p}=0.742)$. Similar results were also found in the study of Yuan et al, 2014 which found that the VEGF gene polymorphism $-460 \quad \mathrm{C} / \mathrm{T}$ rs833061 was an irrelevant factor with the risk of $\mathrm{DR}$ in patients with diabetes mellitus. ${ }^{9}$

\section{CONCLUSION}

Based on this study, it can be concluded that VEGF gene polymorphism 460C/T (rs833061) is not a risk factor for DR in T2DM patients in Bali. Further study needs to be done to find out other parameters and variable that might be related between VEGF gene polymorphism -460C/T (rs833061) and DR in T2DM with more comprehensive design and larger sample size.

\section{ACKNOWLEDGEMENT(S)}

We would like to thank every author that have been involved in this study from the beginning until publication process.

\section{Conflict of Interest: None}

Source of Funding: The Institution of Research and Community Services of Udayana University, Denpasar, Bali. Number: B/6546-3/UN14.2.2.VII.1/PT.01.03/2021

Ethical Approval: Approved. 461/UN14.2.2.VII.14/LT/2021.

\section{REFERENCES}

1. American Diabetes Association (ADA). American Diabetes Association Standard Medical Care in Diabetes. From: https//www.diabetesed. net. 2018.

2. World Health Organization. Global data on visual impairment. Geneva, WHO. 2015.

3. International Diabetes Federation. IDF Diabetes Atlas $8^{\text {th }}$ ed. Available from: http//www.diabetesatlas.org. 2017.

4. Perkumpulan Endokrinologi Indonesia. Konsesus Pengelolaan dan Pencegahan Diabetes Melitus Tipe 2 di Indonesia. Jakarta: PB PERKENI. 2019.

5. Ilyas SH. Ilmu Penyakit Mata. Edisi ke tiga. Fakultas Kedokteran Universitas Indonesia, Jakarta. 2010.

6. Gong JY, and Sun YH. Association of VEGF gene polymorphisms with diabetic retinopathy: a meta-analysis. PloS one. 2013;8(12):p.e84069.

7. Paine SK, Basu A, Mondal LK, Sen A, Choudhuri S, et al. Association of vascular endothelial growth factor, transforming growth factor beta, and interferon gamma gene polymorphisms with proliferative diabetic retinopathy in patients with type 2 diabetes. Molecular vision. 2012;18:p.2749.

8. Yang X, Deng Y, Gu H, Ren X, Li N, et al. Candidate gene association study for diabetic retinopathy in Chinese patients with type 2 diabetes. Molecular vision. 2014; 20: p.200.

9. Yuan Y, Wen Z, Guan Y, Sun Y, Yang J, et al. The relationships between type 2 diabetic retinopathy and VEGF-634G/C and VEGF-460C/T polymorphisms in Han Chinese subjects. Journal of Diabetes and Its Complications. 2014;28:785-790. 
Astri Meliana et.al. Vascular endothelial growth factor (VEGF) -460C/T (rs833061) gene polymorphism as a risk factor for diabetic retinopathy in type 2 diabetes mellitus in Bali.

10. Yang $\mathrm{X}$, Deng $\mathrm{Y}, \mathrm{Gu} \mathrm{H}$, Lim A, Altankhuyag A, et al. Polymorphisms in the vascular endothelial growth factor gene and the risk of diabetic retinopathy in Chinese patients with type 2 diabetes. Molecular Vision. 2011;17:3088-3096.

11. Chisha Y, Terefe W, Assefa H, and Lakew S. Prevalence and factors associated with diabetic retinopathy among diabetic patients at Arbaminch General Hospital, Ethiopia: Cross sectional study. PLOS One. 2017;12(3): 0171967.

12. Maghbooli Z, Pasalar P, Keshtkar A, Farzadfar F, Larijani B. Predictive factors of diabetic complications: a possible link between family history of diabetes and diabetic retinopathy. Journal of diabetes \& metabolic disorders. 2014;13(1):1-5.

How to cite this article: Meliana A, Wihandani DM, Ni Nyoman Ayu Dewi et.al. Vascular endothelial growth factor (VEGF) -460C/T (rs833061) gene polymorphism as a risk factor for diabetic retinopathy in type 2 diabetes mellitus in Bali. International Journal of Research and Review. 2021; 8(12): 1-6. DOI: https://doi.org/10.52403/ijrr.20211201 